\title{
Gender inequality on the labour market in the Czech Republic
}

\author{
Kamila Vesela $^{1, *}$ David Krizek $^{1}$
}

${ }^{1}$ Czech University of Life Sciences Prague, Faculty of Economics and Management, Department of Economic Theories, Kamycka 129, 16500 Prague, Czech Republic

\begin{abstract}
Research background: Even though we live in the 21st century, where society is no longer expected to treat women and men differently, the reality is unfortunately different. Gender differences can be observed in virtually every country in the world. In some aspects of gender inequality, the Czech Republic is doing relatively well, for example, in terms of equal access to education, but in other areas it is doing much worse. In the Czech Republic, gender inequality is manifested in particular in the gender pay gap and on the labour market situation, where female unemployment is higher than male unemployment.

Purpose of the article: This article analyses gender inequality in the Czech Republic on the labour market. The aim of this article is to evaluate the state, development and estimate the future direction of the labour market with an emphasis on gender inequality.

Methods: Using time-series analysis of the number of applicants at the labour offices, it assesses the status and development of gender inequality in the labour market. The analysis also includes a prediction of future developments, where the author seeks an answer to the question whether the gender gap in this area is decreasing or increasing over time.

Findings \& Value added: The analysis showed a persistent trend of higher unemployment among women compared to men. However, this gap is decreasing in the long term.
\end{abstract}

Keywords: gender; labor market; unemployment; women

JEL Classification: $J 16$; $J 31 ; J 64 ; J 71$

\footnotetext{
${ }^{*}$ Corresponding author: veselakamila@pef.czu.cz
} 


\section{Introduction}

Discrimination comes in many forms and shapes, which is one of the reasons why research into its causes and consequences is so important. It is a type of human and systemic behaviour that disadvantages a group on the basis of various characteristics or specifics. Economics also seeks to contribute to the debate and to expose the persistence of discrimination not only in economic areas. This article primarily focuses on the labour market and discrimination that is implemented on the basis of gender, i.e., the dixrimination of women. Many important and historical works have addressed their status and gender role, for example Becker (1985, 1991), Goldberg (1999). There are several forms of discrimination (Pendleton, 2021), as Brozova (2006) states, we can identify 4 basic forms of discrimination in the labour market:

- $\quad$ wage (based on wage inequality for identical labour productivity);

- $\quad$ employment (preference for employing men at identical labour productivity);

- professional (restrictions on entry into certain sectors and, conversely, pressure to enter others)

- access to human capital (difficult access to labour productivity-enhancing opportunities).

However, it is not only the employment relationship in which asymmetry can be identified. Men are more prevalent among entrepreneurs because of the greater number of barriers imposed on women (Bosma et al., 2012). As reported by Lukes (2013), 2.6 times more men than women started businesses in the Czech Republic at the turn of the decade. This number then showed an increasing tendency, as Lukes (2012) points out again. On the other hand, certain changes can be identified that have a reverse character. More and more women are entering the labor market (Hoffman and Averett, 2010) and Mateju (2015) points out that men are no longer favored in access to higher education, but currently more women. On the other hand, the growth of competition in the labour market will only be evident among women with higher education.

Gender equality is important for many reasons, so it needs to be studied and evaluated, as well as providing economic policy makers with the tools to eliminate it. Based on many indicators, such as the gender gap index, Kreckova Kroupova and Rezankova (2016) show that there is a positive relationship between gender equality in a country and its competitiveness, as well as the gross domestic product per capita indicator. Similarly, for example, Cuberes and Teignier (2014).

The causes of wage inequality can then be found in many areas, be it market production (Albanesi and Olivetti, 2009), international trade (Berik et al., 2004) or a country's export orientation (Dominguez-Villalobos and Brown- Grossman, 2010), taxes and transfers (Blundell et al., 2015), globalization (Oostendorp (2009)) or education (Schwartz and Han, 2014).

One solution to the gender pay gap is offered by Bennedsen et al. (2019), who use the example of Denmark legislating to provide gender pay statistics to confirm that the gender pay gap can be reduced by law. First and foremost, however, by slowing down wage growth for men. In contrast, Morchio and Mosel (2020) refute, on the basis of an empirical equilibrium model, that equal-treatment policies eliminate the gender pay gap.

The aim of this article is to evaluate the status and development of gender inequality on the labour market, or to assess whether there is a difference in unemployment between men and women in the Czech Republic. The main objective is to determine whether this gap exists and how it has evolved over time. A further sub-objective is to compare the unemployment gap between men and women in the Czech Republic with the average value of this gap in the European Union. 


\section{Data base and methodology}

The key source of data for this research is data from the official website of the Czech Statistical Office (CSO) for the period 2005-2020 and Eurostat. The data base consists of quarterly data on the development of unemployment of men and women in the Czech Republic and the countries of the European Union. In the case of the European Union countries, data for the EU-27 (from 2020) and EU-28 (until 2020) are used. Both absolute data on the number of unemployed and the unemployment rate will be analysed, as well as differential indicators, in particular the difference between male and female unemployment.

Basic statistical descriptors (Hendl, 2016) were used to describe the quarterly averages of male and female unemployment and the year-on-year rates of these absolute indicators as well as the relative differences between male and female unemployment. The issue of time series and their parametric and non-parametric modelling of trends is covered, for example, in Cowperthwait and Metcalf (2009). Time series trend analysis methods were used to analyse and forecast the gender unemployment gap for 2021-2022. The choice of appropriate trend function was assessed using interpolation criteria (Brockwell and Davis, 2002) and criteria from regression analysis. The selected function is the one that shows the smallest value of the Mean Square Error (MSE) criterion, is classified as statistically significant using the F-test and the coefficient of determination $\left(\mathrm{R}^{2}\right)$ was able to explain a sufficient percentage of the variability of the dependent variable.

The MSE value is determined using the formula:

$$
M S E=\frac{\sum_{t=1}^{T}\left(y_{t}-\widehat{y_{t}}\right)^{2}}{T}
$$

where $\mathrm{T}$ is the number of observations, $y_{t}$ are the measured values and $\widehat{y_{t}}$ are the expected values. This is one of the most commonly used methods among the interpolation criteria and the best function is normally the one with the smallest MSE value. Linear and quadratic regression functions were used as the baseline functions with respect to time series evolution. Regression analysis has also been used by Stanley and Jarrell (1998) to analyse possible gender bias in wage discrimination.

\section{Results}

In the first phase of the research, the development of absolute indicators on the development of unemployment of men and women was assessed. Figure 1 shows the persistence of higher unemployment among women compared to men. The only period when female unemployment fell below male unemployment was the period of 2008. The analysis of the long-term trend shows a 'closing of the scissors' of the unemployment gap between men and women. To conduct the trend analysis, the following null and alternative hypotheses were set:

$\mathrm{HO}_{1}$ : The differences in unemployment between men and women in the Czech Republic are random.

$\mathrm{H} 1_{1}$ : The differences in unemployment between men and women in the Czech Republic are not random.

The evolution of the gender unemployment gap can be described by a linear function. It was able to explain $89.09 \%$ of the variability of the dependent variable. We assess the significance of the model using the p-value (i.e., the lowest significance level at which we reject the null hypothesis of model insignificance), which shows a value of 0.000036 . The $p$ - 
value is smaller than the standard 5\% significance level and therefore the null hypothesis of non-significance of the linear function can be rejected.

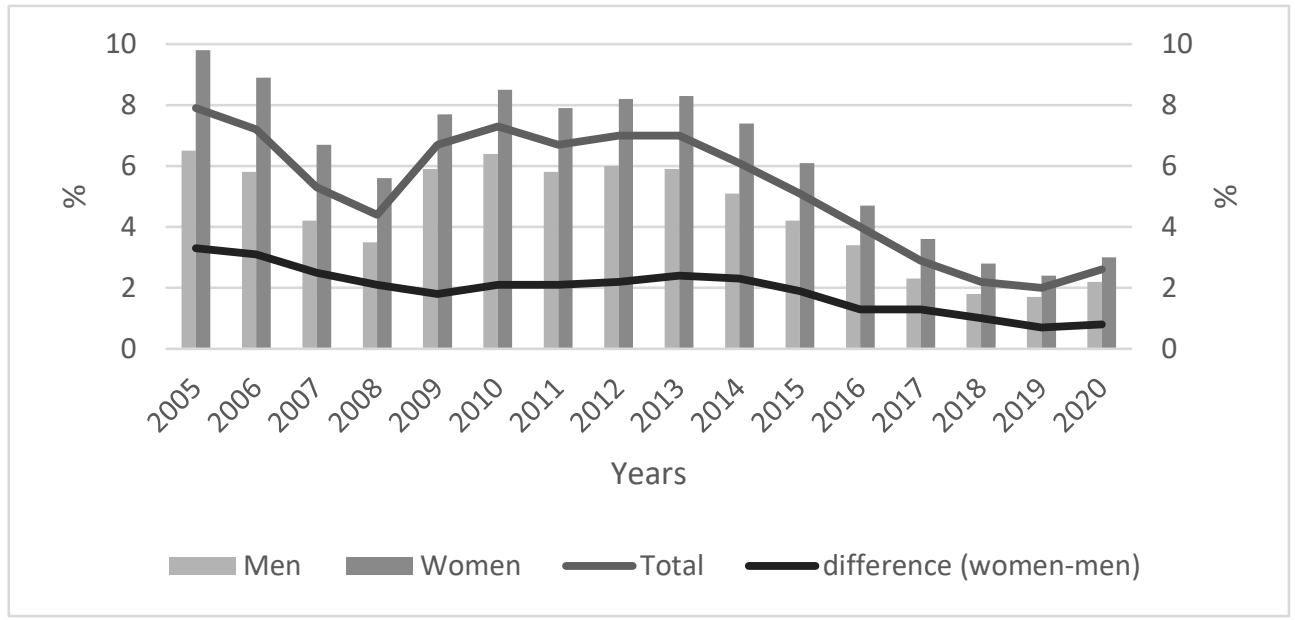

Figure 1. Development of unemployment of men and women in the Czech Republic

Source: own processing based on data from www.czso.cz

The estimate of the regression coefficient $\left(\beta_{0}\right)$ gives a value of 3.13 , while the estimate of the parameter $\beta_{1}$ gives a value of -0.14 . The MSE criterion - "mean square error" - has a value of 0.11 .

The estimation of the function parameters is as follows:

$$
y=3.13-0.14 t
$$

The described linear function shows a statistically significant estimation of the behaviour of the unemployment gap between men and women. This function can be used to model the prediction for the following years. It expects a slow reduction in the unemployment gap between men and women.

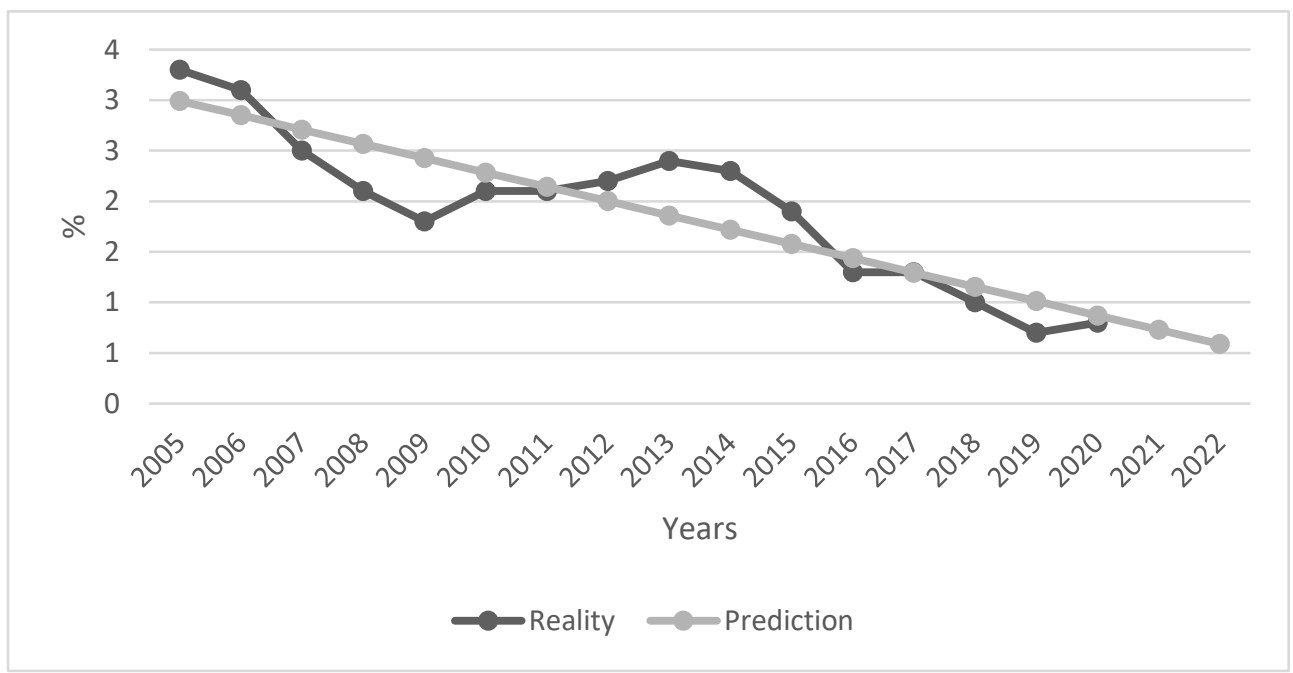

Figure 2. Forecast of the unemployment gap between men and women in the Czech Republic Source: own processing based on data from www.czso.cz 
Despite the fact that the gender gap in the labour market is decreasing, the Czech Republic is one of the countries where the gender gap is quite significant compared to the EU countries. The following Figure 3 shows a comparison of the gender gap in unemployment in the Czech Republic with the EU27 and EU28.

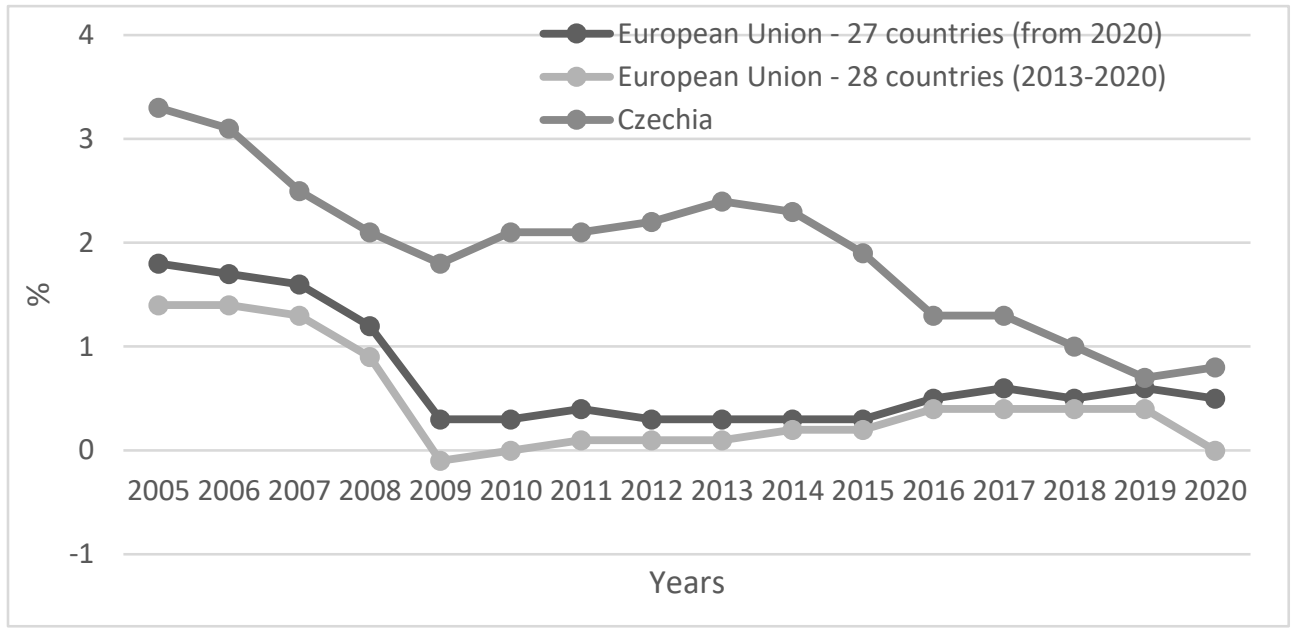

Figure 3. Comparison of the unemployment gap between men and women in the Czech Republic and EU countries

Source: own processing based on Eurostat data (https://ec.europa.eu/eurostat/data/database)

The graph clearly shows several outcomes: 1) the gender gap in unemployment in the Czech Republic is significantly higher than the average in the European Union; 2) over the period under review, the unemployment gap between men and women in the Czech Republic has been decreasing; 3 ) over the period under review, the unemployment gap between men and women in the Czech Republic and the EU countries has been converging; 4) over the last two years of the period under review, the unemployment gap between men and women in the Czech Republic has been growing again and, on the contrary, decreasing in the EU countries.

The results of the trend analysis of the unemployment gap between men and women in the EU countries also showed a clear trend. In the case of the EU-27 countries, a quadratic function can be used to model the behaviour of the gender unemployment gap. It can explain $91.56 \%$ of the variability of the dependent variable. We assess the significance of the model using the p-value (i.e., the lowest significance level at which we reject the null hypothesis of insignificance of the model), which shows a value of 0.000072 . The p-value is smaller than the standard chosen significance level of $5 \%$ and therefore the significance of the quadratic function can be indicated. The estimate of the regression coefficient $\left(\beta_{0}\right)$ gives a value of 2.25 , the estimate of the parameter $\beta_{1}$ gives a value of -0.38 and the coefficient $\beta_{2}$ gives a value of 0.02 . The MSE criterion - "mean square error" - has a value of 0.05 .

The estimation of the function parameters is as follows:

$$
y=2.25-0.38 t+0.02 t^{2}
$$

The described quadratic function shows a statistically significant estimation of the behaviour of the unemployment gap between men and women in EU countries.

Similarly, in the case of the EU-28 countries, a quadratic function can be used to model the behaviour of the unemployment gap between men and women. It can explain $82.29 \%$ of the variability of the dependent variable. We assess the significance of the model using the p-value (i.e. the lowest significance level at which we reject the null hypothesis of insignificance of the model), which shows a value of 0.00064 . The p-value is smaller than 
the standard chosen significance level of $5 \%$ and therefore the significance of the quadratic function can be indicated. The estimate of the regression coefficient $\left(\beta_{0}\right)$ gives a value of 1.76 , the estimate of the parameter $\beta_{1}$ gives a value of -0.32 and the coefficient $\beta_{2}$ gives a value of 0.02. The MSE criterion - "mean square error" - has a value of 0.08 .

The estimation of the function parameters is as follows:

$$
y=1.76-0.32 t+0.08 t^{2}
$$

The described quadratic function shows a statistically significant estimation of the behaviour of the unemployment gap between men and women in EU countries (28).

\section{Discussions}

The existence of gender inequality in the Czech Republic is unfortunately a reality. Despite the fact that we live in modern times, in the 21 st century, there are unfortunately still areas where women are in a worse situation than men. The most common manifestation of gender inequality is gender pay inequality (Almquist, 1987), which is also present in the Czech Republic. However, the aim of this article was to assess the impact of gender on the labour market, or to identify and evaluate whether there is a difference in unemployment rates between men and women. The research has clearly shown that the situation persists where there are more unemployed women than men. At the same time, however, it was described that there is a downward trend or that the unemployment gap between men and women in the Czech Republic is decreasing. In the case of entrepreneurship, on the other hand, the situation is reversed, as shown by Lukes (2013). An exception is the period of the last two years, when the difference in the unemployment rate between men and women increased again, but this can be attributed to the difficult global situation related to the so-called Coronavirus crisis (Chung, 2021), which had a significant impact on the unemployment rate. The article also compared the unemployment gap between men and women in the Czech Republic with the situation in the European Union, using the values of the unemployment gap between men and women in the EU countries (27) and the EU(28). In both cases, the Czech Republic performs significantly worse than the average of the EU countries, although the gap is decreasing over time.

\section{References}

1. Albanesi, S., \& Olivetti, C. (2009). Home production, market production and the gender wage gap: Incentives and expectations. Review of Economic dynamics, 12(1), 80-107.

2. Almquist, E. M. (1987). Labor market gender inequality in minority groups. Gender \& Society, 1(4), 400-414.

3. Becker, G. S. (1985). Human capital, effort, and the sexual division of labor. Journal of Labor Economics, 3(1), 33-58.

4. Becker, G. S. (1991). A Treatise on the Family. Cambridge, Massachusetts, Harvard: University Press. ISBN 978-0674906990.

5. Bennedsen, M., Simintzi, E., Tsoutsoura, M., \& Wolfenzon, D. (2019). Do firms respond to gender pay gap transparency? (No. w25435). National Bureau of Economic Research.

6. Berik, G., Rodgers, Y. V. D. M., \& Zveglich, J. E. (2004). International trade and gender wage discrimination: Evidence from East Asia. Review of Development Economics, 8(2), 237-254. 
7. Blundell, R., Graber, M., \& Mogstad, M. (2015). Labor income dynamics and the insurance from taxes, transfers, and the family. Journal of Public Economics, 127, 5873.

8. Bosma, N.,Wennekers, S., and Amoros, J.E. (2012). Global Entrepreneurship Monitor. 2011 Extended Report. Entrepreneurs and Entrepreneurial Employees Across the Globe. www.gemconsorium.org

9. Brockwell, P. J., Davis, R. A. (2002). Introduction to Time Series and Forecasting. New York: Springer. ISBN 978-0-387-95351-9.

10. Brozova, D. (2006). Diskriminace zen v ekonomicke teorii vybrane problemy [The economics of sex discrimination]. Politicka ekonomie, 2006(5), 646-660.

11. Cowpertwait, P. S., \& Metcalfe, A. V. (2009). Introductory time series with R. Springer Science \& Business Media.

12. Dominguez-Villalobos, L., \& Brown-Grossman, F. (2010). Trade liberalization and gender wage inequality in Mexico. Feminist Economics, 16(4), 53-79.

13. Goldberg, S. (1999). Why Men Rule: A Theory of Male Dominance. Chicago: Open Court, 1999. ISBN 978-0812692372.

14. Hendl, J. (2016) Kvalitativni vyzkum: zakladni teorie, metody a aplikace, Portal, ISBN: 978-80-262-0982-9.

15. Hoffman, S. D., Averett, S. L. (2010). Women and the Economy. Family, Work, and Pay. Second edition. Boston: Pearson, Addison-Wesley. ISBN 978-0-321-41094-8.

16. Chung, H., Birkett, H., Forbes, S., \& Seo, H. (2021). Covid-19, Flexible Working, and Implications for Gender Equality in the United Kingdom. Gender \& Society, 35(2), 218 232.

17. Kreckova Kroupova, Z., \& Rezankova, H. (2016). Relationship of gender gap, competitiveness and sustainability of economy-position of the Czech Republic in international comparison. Politicka Ekonomie, 64(4), 468-491.

18. Lukes, M., Zouhar, J., Jakl, M., \& Ocko, P. (2013). Faktory ovlivnujici vstup do podnikani: zacinajici podnikatele v Ceske republice. Politicka ekonomie, 61(2), 229247.

19. Lukes, M.; Jakl, M. (2012). Podnikani v Ceske republice. Praha: Oeconomica.

20. Mateju, P., \& Vecernik, J. (2015). Skills, Education and Human Capital in the Czech Republic in tThe View of OECD-PIAAC Survey. Politicka ekonomie, 63(2), 185-203.

21. Morchio, I., and Moser, C. (2020). The gender pay gap: Micro sources and macro consequences. Available at SSRN 3176868.

22. Oostendorp, R. H. (2009). Globalization and the gender wage gap. The World Bank Economic Review, 23(1), 141-161.

23. Pendleton, J. (2021). (En) Gendering the word 'midwife': semantics, etymology and orientations. Journal of Gender Studies, 1-13.

24. Schwartz, C. R., \& Han, H. (2014). The reversal of the gender gap in education and trends in marital dissolution. American sociological review, 79(4), 605-629.

25. Stanley, T. D., Jarrell, S. B. (1998). Gender Wage Discrimination Bias? A MetaRegression Analysis. Journal of Human Resources, 33(4), 947-973. 